\title{
Menelisik Sumbangan Islam Bagi Peradaban Modern
}

\section{Wahyudin Noor}

STAIN Syaikh Abdurrahman Siddik Bangka Belitung, Indonesia

wahyudinnoor@gmail.com

\begin{abstract}
Islamic contributions to modern civilization, include: first, the contribution of Islam in modern science in a system of belief based on monotheism; secondly, in the political sphere, that Islam and democracy are essentially compatible, viable, and should be seen as a continuation or development of the Islamic "democratic" model; thirdly, for Islamic economics, starting from pioneering thinking to the continued to application of the system as part of the economic development of Islamic contributions to modern civilization; fourth, for social issues divided over human rights and women's status in Islam it opens up a golden opportunity for the Muslim community to radically revise the whole system of traditional thought toward a new system of thought, both in the Islamic horizon and the historical horizon of comparison; comparisons between Islam, Christianity, and Judaism, and specifically the comparison between Islam and modern Western achievements to the present day.
\end{abstract}

Keywords: Islamic contributions, modern civilization

Received: 05-06-2017; accepted: 16-06-2017; published: 01-07-2017 


\section{A. Pendahuluan}

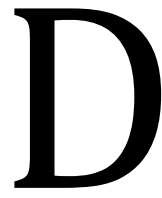

unia sedang berubah, setiap hari manusia nampak terus maju ke tingkatan otonomi yang lebih besar, sebagaimana ia juga mengupayakan kemerdekaan yang lebih besar. Kemajuan ilmu pengetahuan dan penemuan-penemuan teknologi telah memberi dua tanda mata bagi masa kita berupa rasionalisasi dan efisiensi. Begitu berlebihannya sehingga orang sering sekali mendistorsi fakta modernitas dengan apa yang semestinya lebih merupakan ideologi modernisme. Namun, harus dipahami disini bahwa tetap saja gagasan modernisasi pada masa kini mempunyai konotasi yang paling positif. Untuk mencapai makna itu, kita juga harus menerima prinsip-prinsip modernitas: rasionalitas, perubahan dan kemerdekaan.

Tentu saja, ini merupakan persoalan yang belum selesai di awal millennium ketiga dalam rangka mengetahui apakah Islam dan kaum muslim akan ikut serta dalam kereta kemajuan. Membandingkan dunia Barat yang secara permanen dikendalikan oleh ledakan sains dan teknologi, dengan dunia Islam yang tak pelak lagi masih terpaku pada masa-masa gemilang, berpegang teguh pada tradisi-tradisi yang mencampurkan kebudayaan lokal dengan rujukan-rujukan Qur'anik -tentu sangat menarik. Seorang mungkin bertanya apakah menolak kemajuan modernitas tidaklah inhern dalam Islam itu sendiri. Yang demikian itu kontras, seperti dinyatakan sebagian orang, bahwa merupakan kewajiban "memodernisasi Islam" jika ada kesempatan menyaksikan kaum muslimin hidup dalam harmoni dengan masa mereka, dan agar mereka mampu, pada akhirnya, menyesuaikan diri.

Persoalannya kemudian adalah, akankah dapat dunia Islam memasuki modernitas tanpa mengabaikan prinsip-prinsip dasar ajaran Islam? Apakah dunia Islam mempunyai sarana-sarana untuk membangun hubungan dengan dominasi Barat yang modern dalam menghadapi kekinian sebagai langkah awal dalam memberikan sumbangan Islam terhadap peradaban modern?

\section{B. Sekilas tentang Peradaban Modern}

Sejarah manusia adalah sejarah peradaban itu sendiri. Tidak mungkin berbicara tentang (sejarah) perkembangan manusia -yang membentang di seluruh peradaban, dari Sumeria Kuno dan Mesir hingga peradaban klasik, dari Meso-Amerika hingga peradaban Kristen, dalam peradaban-peradaban Islam dan pengejawantahan suksesif 
peradaban Cina dan Hindu- melalui term-term lain. Seluruh sebab kemunculan, perkembangan, saling keterkaitan-saling keterkaitan, pencapaian-pencapaian, kemunduran dan kejatuhan peradaban telah tereksplorasikan melalui para sejarawan, sosiolog, dan antropolog. Meskipun terdapat perbedaan-perbedaan perspektif, metodologi, titik tekan, konsep, tetapi dalam konteks yang lebih luas, terdapat kesepakatan dalam kaitan dengan proposisi-proposisi sentral mengenai hakikat, identitas, dan dinamika dari masing-masing peradaban.

Bagi Braudel, peradaban adalah sebuah wilayah kultural yang meliputi sekumpulan karakteristik dan fenomena kultural. Dawson, mendefinisikannya sebagai produk dari suatu proses tertentu dari kreatifitas budaya sehingga hasil karya dari sekelompok orang (masyarakat) tertentu. Sementara Durkheim dan Mauss, adalah suatu corak wilayah moral yang melingkupi sejumlah bangsa, dengan kebudayaan masing-masing yang hanya menjadi suatu bentuk tertentu dari keseluruhan. Intinya peradaban adalah entitas paling luas dari budaya. Perkampungan-perkampungan, wilayah-wilayah, kelompok-kelompok etnis, nasionalitas-nasionalitas, pelbagai kelompok keagamaan, seluruhnya memiliki perbedaan kultur pada tingkatan yang berbeda dari heterogenitas kultural. ${ }^{1}$

Sementara kata "modern" dalam sejarah Eropa dipergunakan untuk menyebut suatu periode terakhir dari periodisasi sejarah dunia (Barat). Periode ini bermula dari pergantian abad 15-16, saat ditemukannya daerah-daerah baru oleh orang Eropa, sampai sekarang. Sejak saat itu orang tidak mau lagi untuk terikat dengan pendapat gereja. Dengan gerakan berpikir bebas ini, terutama dalam masalah-masalah ilmu pengetahuan, kemajuan banyak dicapai dalam kemudahan-kemudahan material. Maka modern pun mengandung arti kemajuan. ${ }^{2}$

Orang dapat dan telah banyak memberikan definisi yang berbeda-beda tentang "modern", tetapi semuanya tidak terlepas dari makna kata kerjanya yang menunjuk kepada "masa kini" dan perbedaan itu terletak pada apa yang sebenarnya menjadi ciri dari manusia atau sesuatu "masa kini" itu. ${ }^{3}$

\footnotetext{
${ }^{1}$ Samuel P. Huntington, Benturan Peradaban Antarperadaban dan Masa Depan Politik Dunia, terj. M. Sadat Ismail, (Jakarta : Al-Qalam, 2006), pp. 37-42

2 H.M.Wajiz Anwar, Islam dan Modernisasi, (Yogyakarta : Ratu Ibu, 1980), pp. 13-18

3 Machasin, Kumpulan Naskah Perkuliahan Pemikiran dan Peradaban Islam, (Yogyakarta: UIN Sunan Kalijaga, 2007), p. 90.
} 
Jadi, yang dimaksud dengan peradaban modern adalah entitas kultural yang mencakup nilai-nilai, norma-norma, institusi-institusi dan pola-pola pikir yang menjadi bagian terpenting dari suatu masyarakat terkini yang maju dan terwariskan dari generasi ke generasi.

\section{Sumbangan Islam \\ 1. Ilmu Pengetahuan}

Ilmu pengetahuan modern selama ini diartikan dengan banyak makna, tapi untuk memudahkan pembahasan, kita batasi pengertian kata itu sebagai definisi untuk tingkat mutakhir perkembangan peradaban umat manusia secara keseluruhan yang karena berbagai hal, kebetulan, dimulai oleh bangsa-bangsa dari kawasan Eropa Barat Laut. Ciri peradaban mutakhir itu ialah teknologi. Teknologi ini, pada gilirannya, ditopang oleh suatu sistem kognitif yang dilandasi oleh empirisme, dan inilah yang kita masudkan dengan ilmu pengetahuan modern. Selain empirisme yang amat menonjol, ilmu pengetahuan modern juga berbeda dengan ilmu pengetahuan klasik karena sikapnya yang selalu memandang ke depan, sehingga ilmu pengetahuan menjadi tidak berhenti pada suatu tapal batas (frontier). Karena itu, eksplorasi dan riset merupakan bagian mutlak ilmu pengetahuan modern.

Meskipun abad modern, kebetulan, dimulai oleh Eropa Barat Laut, namun sesungguhnya bahan-bahan pembentuk kemodernan itu berasal dari pengalaman hampir seluruh umat manusia -dari Cina di timur sampai Spanyol di barat. Karena rentang daerah peradaban umat manusia pra modern itu berpusat pada kawasan Timur Tengah dengan budaya Islamnya, maka yang paling banyak memberi sumbangan bahan klasik bagi timbulnya abad modern itu ialah peradaban Islam. Dalam kosa kata ilmu pengetahuan modern dapat kita temukan berbagai "jejak kaki" yang menunjukkan bahwa sumbangan Islam itu terutama berwujud berbagai bahan yang merupakan high culture umat manusia saat itu -dan sampai batas tertentu, juga saat sekarang - sebagaimana tercermin pada istilah-istilah ilmiah, seperti aljabar (aljabr), alkohol (al-kuhul), asimut (al-sumt), logaritma (al-khawarizmiyyah), cipher (alsifr), dan lain-lain. Tidak seluruh bahan peradaban Islam itu dihasilkan oleh kreasi umat Islam sendiri. Selain berkreasi, umat Islam klasik juga berfungsi sebagai "penengah" dan "saksi" keseluruhan umat manusia. Fungsi itu dijalankan dengan menerapkan sikap terbuka terhadap ilmu pengetahuan dan peradaban umat-umat 
lain. Sikap ini melahirkan sikap-sikap lebih lanjut yang tidak segan mengambil sesuatu yang baik dan bermanfaat dari umat lain. Dalam perspektif inilah bisa dipahami sabdasabda Nabi bahwa "hikmah (ilmu pengetahuan, wisdom) adalah barang hilang kaum beriman, sehingga siapa pun dari mereka menemukannya, hendaknya ia mengambilnya", dan hendaknya kita menuntut ilmu pengetahuan, meskipun harus "ke negeri Cina".

Karena itu, sejarah mencatat bahwa umat Islam adalah kelompok umat manusia yang pertama menginternasionalkan ilmu pengetahuan. Jika sebelumnya suatu cabang ilmu pengetahuan hanya merupakan kekayaan nasional bangsa tertentu, seperti Yunani, Persia, India dan Cina, maka sejak Islam dan dalam peradaban Islam, ilmu-ilmu itu tumbuh menjadi kekayaan bersama umat manusia. Penjelasan mendasar atas kenyataan-kenyataan itu terdapat dalam weltanscahung Islam, yang memandang bahwa umat manusia (anak cucu Adam) adalah makhluk Tuhan, yang ditunjuk untuk menjadi khalifah bagi-Nya di bumi. Dalam al-Qur'an diterangkan bahwa kelebihan Adam atas para malaikat, sehingga ia berhak dijadikan khalifah, ialah bahwa Tuhan memberinya ilmu pengetahuan dan kemampuan mengenali lingkungannya. Dan lingkungan itu ialah seluruhjagat raya (langit dan bumi) yang ditegaskan sebagai yang diciptakan oleh Tuhan untuk kepentingan umat manusia.

Jadi, memahami lingkungan hidup, baik yang fisik maupun yang sosio-kultural, dapat dipandang sebagai pemenuhan fungsi kekhalifahan manusia. Hal itu juga berarti usaha memahami sunatullah (hukum-hukum Tuhan) yang telah ditetapkan-Nya. Semua itu melahirkan ilmu pengetahuan, termasuk ilmu pengetahuan modern. Maka bertindak dengan berpedoman pada hasil-hasil penemuan ilmiah adalah bertindak sesuai dengan sunatullah. Dengan kata lain, hal itu merupakan suatu bentuk ketundukkan kepada Allah, dan berarti pula suatu bentuk keislaman. Oleh karena itu, al-Qur'an menyebutkan bahwa dosa terbesar manusia yang tak terampuni ialah syirik. Sebab syirik, yang sebenarnya merupakan takhayul itu, menghalangi manusia dari kemungkinan memahami alam dan masyarakat lingkungannya secara obyektif. ${ }^{4}$

Dalam hemat penulis menjadi jelas, bahwa sumber sumbangan Islam bagi ilmu pengetahuan ialah paham tauhid: monoteisme yang tegas dan tidak mengenal

${ }^{4}$ Nurcholish Madjid, Islam, Kemodenan dan Keindonesiaan (Bandung: Mizan, 1998), cet. ke- XI, pp. 274-276. 
kompromi. Tauhid -juga bisa disebut sebagai paham Ketuhanan Yang Maha Esa adalah ajaran yang menegaskan bahwa tuhan adalah asal-usul dan tujuan hidup manusia, termasuk peradaban dan ilmu pengetahuannya.

Namun, kini muncul banyak kritik kepada peradaban modern dengan teknologi dan ilmu pengetahuannya itu. Seperti halnya muncul budaya hippies \& vegabond, dimana kemajuan ilmu dan teknologi yang selama ini mendomonasi kehidupan masyarakat modern ternyata harus dibayar dengan social cost, yakni berupa pelarian melalui minum-minuman keras, sex bebas, obat-obat terlarang dan lain sebagainya. Dari sudut pandang Islam, hanya segi metode dan empirisme ilmu pengetahuan modernlah yang nampaknya absah (valid). Sedangkan dalam hal moral dan etika, ilmu pengetahuan modern amat miskin. Disinilah letak inti sumbangan Islam -dengan sistem keimanan berdasarkan tauhid itu, kaum muslimin diharapkan mampu menawarkan penyelesaian atas masalah moral dan etika ilmu pengetahuan modern.

\section{Politik}

Dalam wacana pemikiran Islam tentang politik, salah satu yang menjadi tema sentral pada masayarakat modern saat ini adalah tentang demokrasi. Demokrasi, dalam pengertian seperti itu, sebagaimana dikatakan John L. Esposito dan James P. Piscatory, paling tidak ada tiga kelompok pemikiran. Yaitu, kelompok yang menolak, yang menyetujui prinsip-prinsipnya tetapi mengakui adanya perbedaan, dan yang menerima sepenuhnya. Bagi kelompok yang menolak demokrasi, demokrasi tidak bisa dipadukan dengan Islam, impossible, bahkan merupakan ancaman yang perlu diwaspadai. Yang menganut pemikiran seperti itu antara lain Syaikh Fadhallah Nuri, Sayyid Quthb, al-Sya'rawi, Ali Benhadj dan Thabathabai. Alasan keberatan mereka adalah karena prinsip persamaan demokrasi yang dalam kenyataan tidak mungkin; kesempurnaan Islam sebagai jalan hidup yang karenanya tidak perlu legislasi lain; kedaulatan Tuhan di bumi ini, baik sunnatullah (hukum alam) maupun hukum-hukum wahyu-Nya; syura tidak dengan sendirinya demokrasi; prinsip mayoritas tidak berarti benar dan adil, demokrasi hanya sebagai alat Barat semata, dan dalam sejarah seperti dikutip al-Qur'an mayoritas manusia menolak kehadiran agama-agama besar yang sebab itu mayoritas tidak berarti benar dan adil secara moral. Sedangkan bagi kelompok kedua, Islam (sistem syura) dan demokrasi memang ada kemiripan dalam prinsip-prinsipnya. Misalnya keadilan, persamaan, musyawarah, dan akuntabilitas 
penguasa. Akan tetapi keduanya berbeda dalam soal kedaulatan rakyat. Jika dalam demokrasi, kedaulatan rakyat bersifat mutlak, maka dalam Islam kedaulatan mereka dibatasi oleh kedaulatan Tuhan atau hukum-hukum-Nya (syari'ah). Islam menurut kelompok ini berada di antara sistem theo-krasi dan demo-krasi. Jelasnya sistem politik yang dikehendaki Islam adalah Theo-Demokrasi dalam bahasa al-Maududi atau Theistik demokrasi dalam bahasa Mohammad Natsir. Ini tidak berarti tidak ada ruang sama sekali bagi legislasi, mengingat dalam soal yang tidak diatur syari'ah berlaku ijtihad dan itu adalah wewenang parlemen.

Berbeda dengan dua kelompok yang tidak bisa melakukan sintesa yang viable antara Islam dan demokrasi itu, maka kelompok ketiga melihat sebaliknya. Ajaran Islam tentang politik dan paham demokrasi bisa dipadukan. Kedua-duanya sama, baik dalam prinsip atau prosedur kenegaraan. Bahkan, menurut kelompok ini demokrasi pertama kali dicanangkan Islam. Alasan yang mereka kemukakan adalah, sebagaimana dinyatakan Fahmi Huwaidi, bahwa Islam menghendaki pemerintahan yang disetujui rakyatnya; penolakan Islam terhadap kediktatoran; pemilu sebagai kesaksian rakyat; negara Islam adalah negara keadilan yang menjunjung tinggi toleransi dan pluralisme; demokrasi berarti upaya mengembalikan sistem politik yang dipraktekkan Nabi dan khalifahnya yang sempat hilang di tangan Mu'awiyah dan khalifah Islam setelahnya; dan dalam tradisi pemikiran Islam, imamah (kepemimpinan politik) merupakan kontrak sosial. 5

Dalam pandangan penulis, kelompok pertama dan sebagian kelompok kedua dalam melakukan upaya sintesa yang viable dan compatible antara Islam dan demokrasi tampaknya terbelenggu penafsiran klasik, mengalami psikologi protes terhadap yang berbau Barat. Karena itu, penolakan mereka terhadap demokrasi sebenarnya bukanlah penolakan terhadap demokrasi keseluruhan, tetapi terhadap pengaruh kolonialisme Barat dan karakter sekuler demokrasi. Sedangkan kelompok ketiga, satu hal yang mencolok dari mereka, selain perannya dalam mempertegas kompatibilitas Islam dan demokrasi, adalah juga kecenderungannya untuk mengadaptasi Islam dengan modernitas seperti demokrasi yang terkadang agak

5 Sukron Kamil, Islam dan Demokrasi; Telaah Konseptual dan Historis (Jakarta: Gaya Media Pratama, 2002), pp. 195-197. 
berlebihan. Islam terkesan sebagai alat justifikasi semata terhadap demokrasi versi Barat.

\section{Ekonomi}

Kegiatan ekonomi adalah sesuatu yang jarang terlepas kaitannya dengan politik. Jika usaha untuk membangun negara dengan tatanan Islam sulit terpenuhi, demikian pula dengan tatanan ekonominya. Oleh sebab itu tidak ada suatu negeri Islam pun yang telah merdeka dari penjajahan yang kemudian kembali menggunakan atribut Islam sebagai metode penyusunan lembanganya. Bahkan nama "Baitul Maal" pun sudah tersingkir dari kosa kata pemerintahan mereka. Yang tertinggal oleh mereka adalah negara bekas jajahan yang meniru penjajahnya dengan pemerintah yang baru dan berasal dari mereka sendiri. Mereka merdeka secara politik, tetapi tidak secara sistem, terutama sistem ekonomi. Tanpa diketahui, sistem yang mereka wariskan juga membawa penyakit yang inhern dalam sistem itu, seperti inflasi, pengangguran, resesi dan sebagainya.

Dengan teknologi yang jauh tertinggal, mereka bahkan tidak pernah bisa bersaing dengan negara penjajahnya sehingga hubungan antar keduanya bukan sebagai kompetitor, tetapi sebagai sentral-periferal, pusat dan pinggiran. Hal ini kemudian orang mulai mencari sistem baru yang bisa menyelamatkan masyarakat terutama di negeri-negeri Islam. Meskipun relatif tidak sukses dalam gerakan politikideologis, mereka mencoba membuat terobosan dengan menggunakan idiom ekonomi.

Gerakan lembaga keuangan Islam modern dimulai dengan didirikannya sebuah bank dengan simpanan lokal (local saving bank) yang beroperasi tanpa bunga di desa Mit Ghamir, di tepi sungai Nil, Mesir pada tahun 1969 oleh Dr. Abdul Hamid An-Naggar. Walaupun beberapa tahun kemudian tutup karena masalah manajemen, bank lokal ini mencatatkan sejarah yang amat berarti, karena mengilhami konferensi ekonomi Islam pertama di Makkah pada tahun 1975. Dua tahun kemudian lahir Bank Pembangunan Islam (Islamic Development Bank/IDB) yang merupakan tindak lanjut dari rekomendasi yang lahir dari konferensi ekonomi tersebut. Setelah itu muncul bankbank komersial yang transaksi-transaksinya didasarkan pada ajaran Islam.

Munculnya bank-bank swasta Islam baik tingkat desa maupun internasional, diiringi dengan keperluan akan lembaga-lembaga pendukungnya seperti asuransi. Karena itu biasanya jika ada bank Islam di suatu negara, maka muncul pula asuransi 
Islami (takaful). Tetapi tidak sampai disitu saja. Karena pada saat bersamaan muncul keperluan akan adanya pasar modal yang Islami. Oleh karena itu muncul pula fund manager-fund manager Islam dengan kriteria investasi yang sesuai dengan syariat Islam. Langkah ini ternyata bukan hanya dilakukan oleh kaum muslimin tetapi juga oleh orang lain. Baru-baru ini Dow Jones misalnya mengeluarkan apa yang disebut Islamic Index yang memuat index saham yang diperdagangkan secara Islam.

Meskipun usia masih sangat belia, sistem keuangan Islam tampaknya begitu cepat berkembang dan tumbuh. Jika kelahiran Islamic Development Bank (IDB) pada tahun 1975 dipakai sebagai tonggak lahirnya sistem keuangan secara empiris, maka rentang waktu 27 tahun kemudian sistem ekonomi Islam telah menunjukkan perkembangan yang cukup bagus. Kini telah berdiri lebih dari 200 lembaga keuangan dan investasi Islam.

Setelah tiga dasawarsa, sistem keuangan Islam telah menarik perhatian para investor Barat terutama Eropa. Metode pembiayaan Islam telah dipandang sebagai suatu tantangan sekaligus peluang bagi mereka yang berkecimpung dalam bisnis keuangan modern di Barat. Hal ini dimungkinkan terutama adanya fenomena masyarakat industri yang didorong oleh tuntutan klien dalam nuansa bisnis modern. Dalam masyarakat demikian, selalu timbul kesediaan dari pihak pengelola lembaga keuangan untuk senantiasa mendengarkan dan terus mempelajari perkembangan dan pengalaman bank-bank Islam yang diperkirakan akan menjadi sebuah trend baru dalam sistem keuangan dunia.

Menurut Rodney Wilson, kini sudah ada sembilan lembaga keuangan multinasional yang membuka unit usaha syari'ah di London. Sembilan lembaga keuangan multinasional itu adalah ANZ International, Al-Rahji Banking, Citibank International, Dresdner Klienworth Benson, Hongkong \& Shanghai Banking Corporation, National Commercial Bank, Riyadh Bank Europe, Standar Chartered Bank dan United Bank of Kuwait. Diperkirakan akan terjadi perkembangan lebih besar di masa yangh akan datang sekalipun perkembangan itu mungkin agak terbatas.

Dorongan untuk mengkaji sistem keuangan Islam secara umum terus meningkat tidak saja pada tingkat bisnis empiris, melainkan juga pada tingkat akademis dan kesarjanaan. Kini banyak lembaga pendidikan Islam di Barat yang 
menawarkan program studi ekonomi dan keuangan Islam seperti Loughborough University of Durham di Inggris. ${ }^{6}$

Namun demikian, sistem ekonomi Islam menurut hemat penulis bukanlah sesuatu yang memang betul-betul baru, tapi lebih dari pada sistem alternatif dari kapitalisme Barat yang mengidolakan individu maupun untuk ekonomi terencana dari sosialisme Timur yang mengidolakan negara.

Di samping itu, penulis juga melihat sistem ekonomi Islam yang berkembang saat ini masih banyak berkutat pada permasalahan ekonomi tentang boleh tidaknya sesuatu untuk dilakukan dan tentang bagaimana mengedepankan prinsip barakah dalam menjalankan kehidupan yang tidak identik dengan jumlah materi yang dimiliki seseorang. Dalam hemat penulis, masih jarang sekali tawaran yang diberikan oleh sistem ekonomi Islam dalam memberikan penekanan pada pendekatan yang lebih komprehensif, seperti bagaimana seharusnya meningkatkan kesejahteraan umat bisa dilakukan. Sebab pendekatan yang seperti ini akan lebih banyak memberikan warna yang mendekati permasalahan ekonomi yang secara riil dihadapi oleh umat.

\section{Isu-isu sosial}

Masalah HAM merupakan persoalan aktual yang muncul jauh setelah syari'at dirumuskan; sehingga sudah barang tentu di dalam Qur'an dan Sunnah tidak akan ditemukan kata HAM secara harfiah. Hal yang ada hanyalah norma-norma yang sejalan atau dinilai berhubungan dengan berbagai hak asasi manusia sebagai terdapat dalam deklarasi HAM PBB itu. Untuk keperluan ini diperlukan interpretasi terhadap kedua sumber hukum itu.

Formula syari'at yang berkembang luas di dunia Islam selama ini lebih diwarnai oleh ayat-ayat dan faham-faham yang mendukung adanya perbedaan hak dan perlakuan hukum antara laki-laki dengan perempuan, demikian halnya dengan hak dan kewajiban antara muslim dan non-muslim. Perbedaan hak dan kewajiban itu dipandang sebagai sesuatu yang seharusnya demikian menurut syari'at; sebagai sesuatu yang qat'I yang tidak mungkin lagi untuk diubah. Barulah belakangan muncul gugatan dan tuntutan agar formula syari'at yang demikian itu direformasi atau direaktualisasi karena dipandang sudah tidak relevan dengan perkembangan zaman, dan dinilai tidak kondusif bagi penegakan HAM yang menjadi tuntutan global dewasa

${ }^{6}$ Muhamad, Dasar-Dasar Keuangan Islami, (Yogyakarta: Ekonisia, 2004), pp. 11-13. 
ini. Gugatan dan tuntutan itu, dilakukan antara lain oleh Abdullahi Ahmed al-Na'im, seorang aktivis HAM asal Sudan, yang saat ini menjadi Guru Besar Ilmu Hukum di Emory University Atlanta, Georgia, Amerika Serikat.

Syari'at demikian, yang selama ini dikatakan syari'at oleh kaum muslimin pada umumnya, oleh al-Na'im disebut sebagai syari'at histories, yang merupakan produk sejarah kaum muslimin abad ke-7 sampai 9 Masehi. Menurutnya, syari'at histories ini dibangun dari ayat-ayat Qur'an (dan Sunnah) periode Madinah (madaniyah), yang secara umum dinilai tidak egaliter dan tidak demokratis, tidak kondusif dengan normanorma HAM. Ketika sistem syari'at dirasa sudah tidak relevan atau tidak memadai lagi, sistem tersebut dapat saja diubah dan disesuaikan dengan sistem syari'at baru yang sesuai dengan perkembangan dan kebutuhan masyarakat kontemporer. Dalam kaitan inilah muncul gagasan nash, sebagai metode untuk memilih ayat-ayat mana yang relevan dengan kebutuhan kontemporer itu.

Menurut al-Na'im dan Taha (guru al-Na'im), nash merupakan metode yang memungkinkan untuk memilih atau menunda ayat-ayat tertentu, atas pertimbangan kepantasan dan kesesuaiannya dengan kebutuhan dan perkembangan zaman. Konsep nash yang demikian itu berbeda dengan teori yang ada selama ini, yang lebih memperhatikan pada waktu turunnya ayat. Bagi Taha dan al-Na'im, nash itu lebih menekankan pada hakikat dan kondisi pewahyuan, sehingga bagi mereka pemberlakukan ayat-ayat itu sangat kondisional dan kontekstual. Karena itu, ayat yang sudah mansuh pada waktu tertentu dapat dipergunakan lagi bila kondisinya menghendaki. ${ }^{7}$

Isu sosial lain yang menjadi perhatian masyarakat modern saat ini adalah status wanita dalam Islam. Masalah ini sering diperbincangkan oleh masyarakat muslim sendiri dalam polemik-polemik yang seru dan kontroversial. Namun, hingga sekarang belum memunculkan pemikiran baru dan serius. Jika ada usaha-usaha baru untuk merevisi status wanita yang ditetapkan oleh syari'at, segera muncul suara-suara yang tidak hanya menolak, tapi bahkan mengkafirkan. Fatima Mernissi, Guru Besar di Universitas Rabat, merupakan contoh paling populer. Mernissi yang melontarkan

7 Adang Djumhur S, 'Reformasi Syari'ah untuk Penegakkan HAM: Perspektif Ahmed Al-Na'im', Jurnal Khazanah, vol. 2, no. 7 (2005), pp. 128-139. 
gagasan-gagasan baru tentang status wanita di dunia Islam, kini menghadapi banyak tantangan dari para ulama.

Dalam membicarakan status wanita dalam Islam, menurut Mohammed Arkoun -Guru Besar Sejarah Pemikiran Islam di Universitas Sorbonne Paris, kaum muslimin harus bersedia keluar dari pelbagai klise dan pra-anggapan -baik yang positif maupun yang negatif - menuju tataran yang sama sekali baru. Kaum muslimin tidak boleh menepiskan problem ini dengan berkata bahwa al-Qur'an telah mengangkat status wanita sejajar dengan pria. Selain itu, kaum muslimin juga tidak boleh termakan oleh pandangan Barat yang menyatakan bahwa Islam merendahkan status wanita. Hanya dengan cara keluar dari kedua bentuk klise inilah, kaum muslimin akan berhasil melihat fakta-fakta umum mengenai status wanita di seluruh masyarakat manusia. ${ }^{8}$

\section{Penutup}

Dari pemaparan di atas, ada beberapa hal yang dapat penulis simpulkan berkaitan dengan sumbangan Islam bagi peradaban modern; pertama, sumbangan Islam dalam ilmu pengetahuan modern terletak pada sistem keimanan berdasarkan tauhid, dimana manusia harus kembali disadarkan atas fungsinya sebagai ciptaan Tuhan, yang dipilih untuk menjadi khalifah-Nya, dan harus mempertanggungjawabkan seluruh tindakannya di muka bumi ini kepada-Nya. Ilmu pengetahuan berasal dari Tuhan dan harus digunakan dalam semangat mengabdi kepada-Nya. Kedua, dalam ranah politik, salah satu yang menjadi tema sentral belakangan ini adalah tentang hubungan Islam dengan demokrasi, baik secara konseptual maupun secara historis. Jika secara pemikiran, demokrasi merupakan bagian tak terpisahkan dari nilai-nilai Islam, kendati dalam Islam konsep demokrasi tidak tunggal tetapi terdapat paling tidak tiga atau tepatnya dua mazhab atau konsep, dan itu adalah sesuatu yang absah, maka secara historis ternyata, prinsip-prinsip demokrasi secara esensial telah juga dipraktekkan Islam sejak dini.

Namun demikian, meskipun konsep yang dipahami masyarakat muslim dan sejarah politiknya tidaklah selamanya berjalan dengan demokrasi liberal Barat yang berkembang dalam setting historis mereka, tetapi kesimpulan yang diperoleh adalah

8 Suadi Putro, Mohammed Arkoun tentang Islam dan Modernitas (Jakarta: Penerbit Paramadina, 1998), pp. 93-94. 
bahwa Islam dan demokrasi pada esensinya compatible, dapat viable, dan mesti dilihat sebagai kelanjutan atau pengembangan saja dari model "demokrasi" Islam. Ketiga, untuk ekonomi Islam, berawal dari pemikiran yang bersifat pioneer hingga berlanjut pada penerapan sistem sebagai bagian dari pengembangan ekonomi bagi sumbangan Islam untuk peradaban modern, perlu ditegaskan kembali bahwa sistem ekonomi Islam harus melangkah lebih maju -tidak lagi berkutat pada permasalahan boleh tidaknya melakukan sesuatu atau lebih mengedepankan konsep barokah, untuk lebih memperhatikan bagaimana seharusnya meningkatkan kesejahteraan umat. Dan yang keempat, untuk isu-isu sosial yang terbagi atas HAM dan status wanita dalam Islam ini membuka kesempatan emas bagi masyarakat muslim untuk merevisi secara radikal seluruh sistem pemikiran tradisional menuju suatu sistem pemikiran baru, baik dalam cakrawala Islam maupun cakrawala sejarah perbandingan; perbandingan antara Islam, Kristen, dan Yahudi, serta secara khusus perbandingan antara Islam dengan capaian-capaian Barat yang modern hingga kini.

Dari uraian di atas dapatlah dipahami bahwa modernitas adalah suatu tujuan yang mesti diupayakan dicapai; ia bersifat intrinsik bagi logika manusia dan bukan sesuatu yang diimpor dari bekas penjajah atau pun bertentangan dengan prinsipprinsip dasar ajaran Islam. Karena itu, salah satu yang menjadi tantangan masyarakat muslim dalam usaha mendorong modernisasi adalah membebaskan diri dari suasana psikologis masa lalu yang serba traumatis, dan menggantinya dengan kesanggupan untuk melihat keadaan secara obyektif, tanpa pertentangan dan kesalahpahaman.

Tidak dapat dimungkiri, modernitas terkait erat dengan dominasi Barat, terutama setelah kolonialisme ratusan tahun bangsa Barat. Untuk menjadi modern, kita tidak harus menjadi kebarat-baratan atau kita tidak perlu menjadi Barat untuk bisa modern. Ilmu pengetahuan, teknologi, kreativitas, inovasi, dan pembaruan merupakan "bahan dasar" modernisasi bukan monopoli peradaban tertentu.

Untuk itu, sumbangan Islam bagi peradaban modern harus dilakukan bersamasama dengan Barat. Dan oleh karenanya, dibutuhkan dialog antara dunia Islam dan Barat. Dialog di forum internasional, seperti PBB, merupakan tempat yang ideal untuk mempertemukan kedua peradaban ini. Makna penting dialog ini adalah untuk membangkitkan apresiasi terhadap kebenaran Islam di benak pihak Barat. Dialog ini akan berhasil jika Barat menerima bahwa Islam bukanlah agama semata, namun jalan 
Mawa'izh

hidup untuk semua pemeluknya. Barat harus memahami kenyataan ini dan mengadopsi sikap Islam termasuk sejarahnya dan pentingnya Islam dalam kehidupan semua muslim.

Dunia Islam harus melakukan tindakan nyata untuk membangun kebenaran bahwa Islam dapat berkembang dan memberikan sumbangsih terhadap modernisasi. Ummat Islam harus melakukan itu agar tercapai persamaan antara dunia Islam dan Barat. Ini merupakan cara terbaik untuk mendapatkan penghargaan Barat terhadap Islam. Akhirnya, sikap ini dipilih agar tercipta pemahaman dan harmoni antara dunia Islam dan dunia Barat untuk kepentingan perdamaian dunia dan stabilitas internasional. 
Mawa'izh

\section{DAFTAR PUSTAKA}

Anwar, H.M. Wajiz, Islam dan Modernisasi, Yogyakarta: Ratu Ibu, 1980.

Djumhur S, Adang, 'Reformasi Syari'ah untuk Penegakkan HAM: Perspektif Ahmed AlNa'im', Jurnal Khazanah, vol. 2, no. 7 (2005), pp. 128-39.

Huntington, Samuel P., Benturan Peradaban Antarperadaban dan Masa Depan Politik Dunia, terj. M. Sadat Ismail, Jakarta: Al-Qalam, 2006.

Kamil, Sukron, Islam dan Demokrasi; Telaah Konseptual dan Historis, Jakarta: Gaya Media Pratama, 2002.

Machasin, Kumpulan Naskah Perkuliahan Pemikiran dan Peradaban Islam, Yogyakarta: UIN Sunan Kalijaga, 2007.

Madjid, Nurcholish, Islam, Kemodenan dan Keindonesiaan, cet. ke- XI, Bandung: Mizan, 1998.

Muhamad, Dasar-Dasar Keuangan Islami, Yogyakarta: Ekonisia, 2004.

Putro, Suadi, Mohammed Arkoun tentang Islam dan Modernitas, Jakarta: Penerbit Paramadina, 1998. 